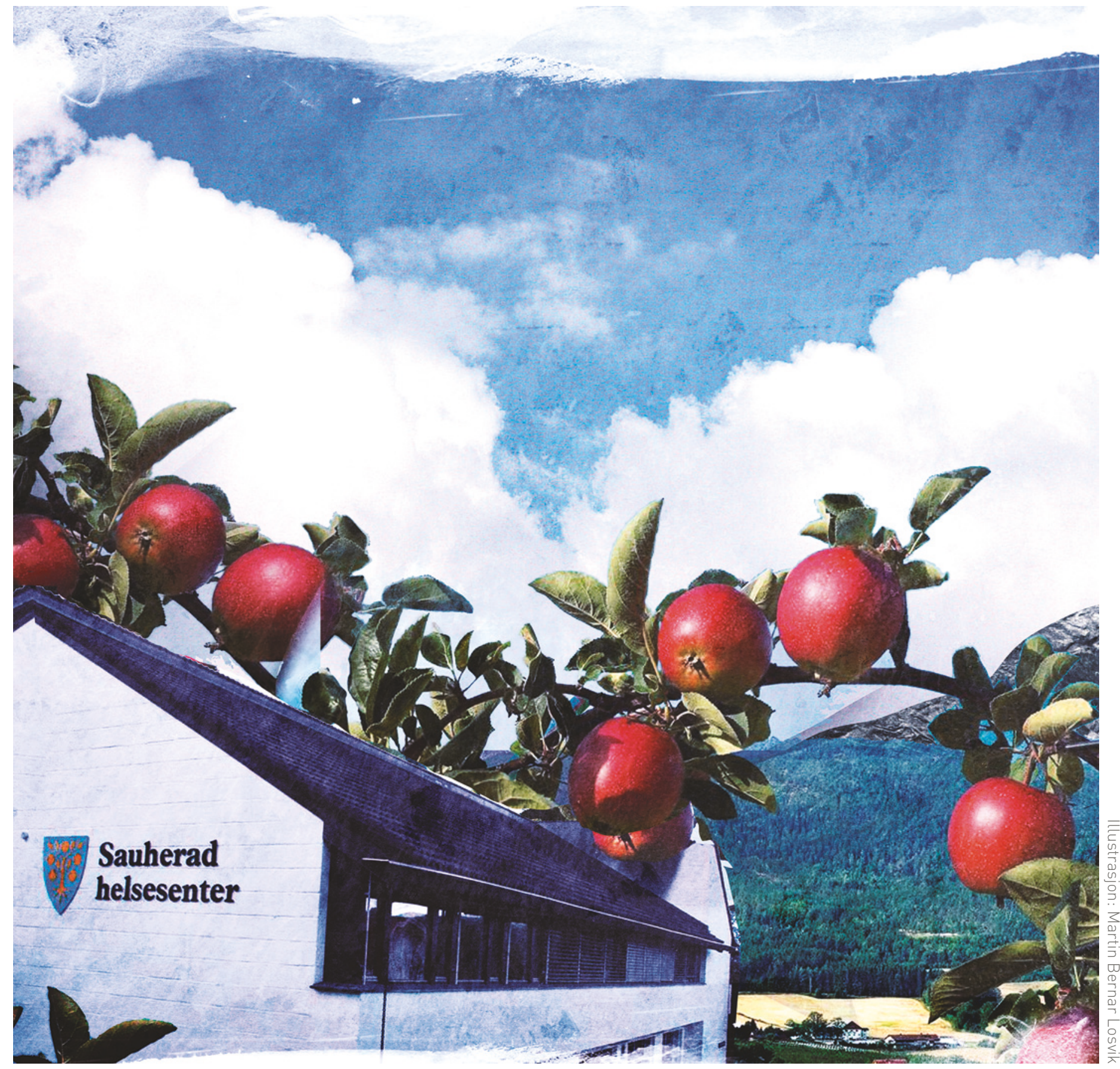

\title{
Sauherad helsesenter
}

(i)

Sauherad helsesenter er lokalisert i eplebygda Gvarv i Sauherad kommune i Telemark.

Kommunen har drøyt 4000 innbyggere. Her finnes legesenter, jordmor, helsestasjon og fysioterapeut. 